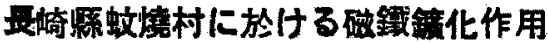

Magnetitization at Kayalki-mura, Nagasaki Prefecture (I)

\author{
年田邦宸 (Kunihiko Muta)*
}

前言

長崎景西彼杵郡地方に露出する蛇絞岩と岩岩との接触部附近では，震々 蛇紋岩化作用後の熱水変質作用によつて滑石化，緑泥石化，孷酸塩化及ひ 陽起石化等がみられるが，此等の変質作用に伴つて，緑泥石化された帯に

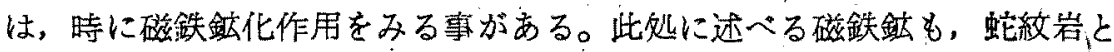
縎雲母・石英・緑泥石・陽起石・曹長石片岩々の接触部にそつて生した緑 泥石化带にみられるもので，緑泥石化作用と此等の磁鉄鉣化作用との間 に泌接な成因的関係を有する事は否めない。今回は主に西彼杵郡忟焼村栄 上に於汁る磁鉄鉿に就いてその産状，共生鉙物との関係及び化学成分を 明らかにし，更に其等の成因に就いて若千の考察をこっろみた。

\section{位置及び地啠概 略}

主題の磁鉄鉣の産地注長崎夺の南方，野母半島のほゔ頚部に位置し，長 崎市より蚊焼及び虑石部落へ至る県道の分岐点より蚊焼部落へ約 $100 \mathrm{~m}$ 程 道路を下つたすぐ南方に位置する。

附近の地質は，緑色片岩及び黒色片岩よりなる結晶片岩類を貫き， 叉一 部は断層関係をもつ蛇校岩の発達がみられる。この蛇效岩は野母半島では 可なり広い区域に亘つて露出し，野母半島の南東方高浜村及び川原村附近 では，野母半島の東海岸より浪中央部を占めて $\mathrm{N} 20^{\circ} \sim 30^{\circ} \mathrm{E}$ 方向に露 出し，為石村に至ると $\mathrm{N} 60^{\circ} \sim 70^{\circ} \mathrm{W}$ 方局で野舟半島をぼ゙東西に樌断し て発達する。此等岩体の傾敘は一般に $20^{\circ}$ 内外の緩傾斜で, 傾斜方向, 脈巾ともに可なりの変化にとみ，その北部為石村附近で注岩の層理に和 行な岩休状で発達する部分が多く，走向は $\mathrm{N} 40^{\circ} \sim 20^{\circ} \mathrm{W}$; 傾斜は一般々北 方へ緩傾斜を示す。この外結晶片岩中には変輝緑岩，変斑粝岩等の貫入を 認むるが，此等火成岩体と磁鉄鉱・緑泥石岩との間には何等直接の関係は

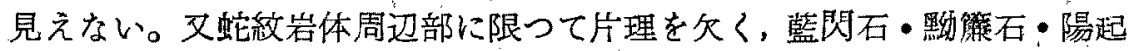
石・曹長石岩を認め，栄上附近でも片岩中にあたかも貫入岩の如き産状で 見出される。此等は或は蛇紋岩をもたらした滬基性岩漿よりの分泌脈とも

* 九州大学工学部採鉣学教室 
第 1 図里半島北部地筫図

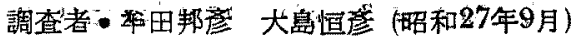

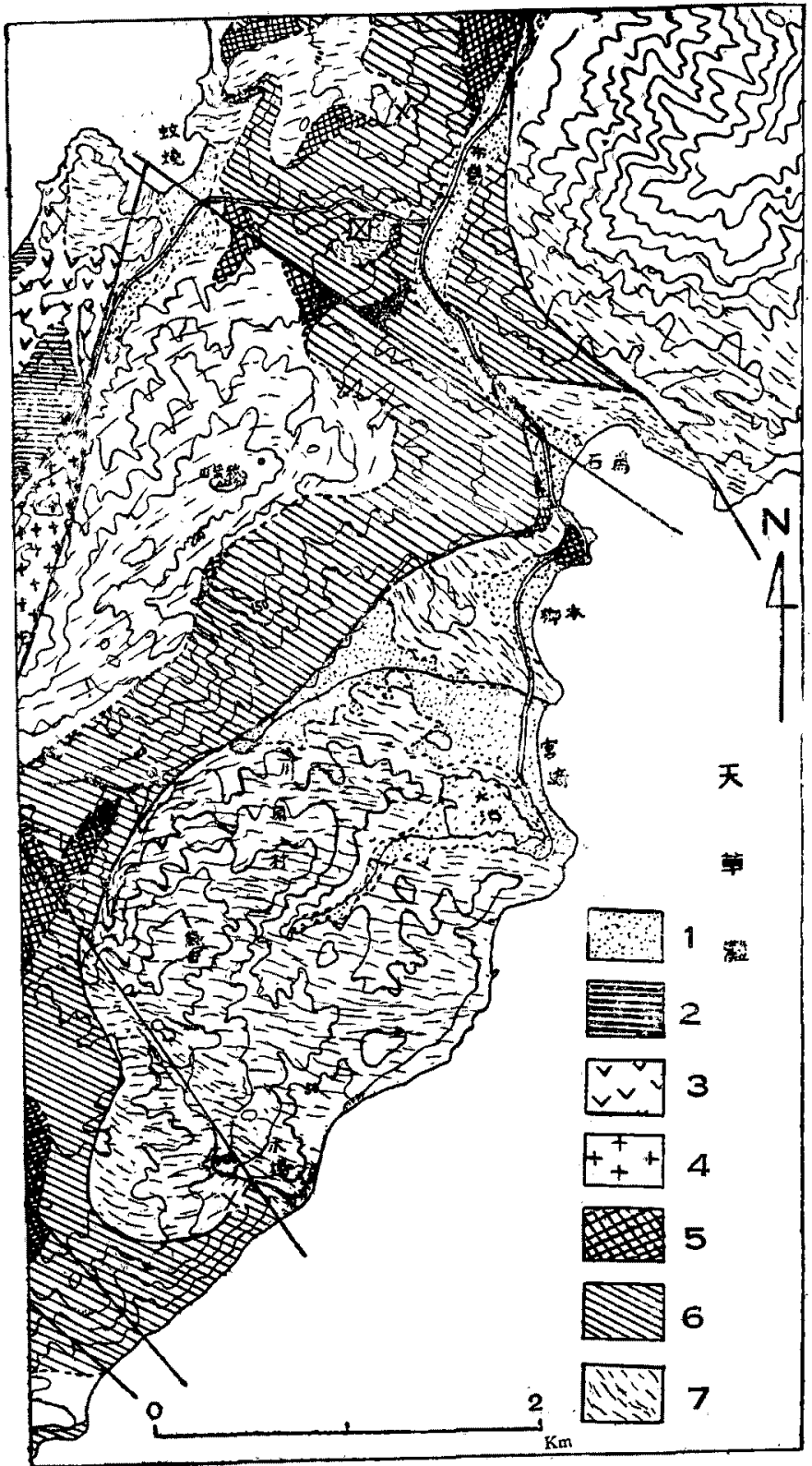

1 ・冲栍畨

2. 品第三紀系

2. 要輝緑岩

4. 帘成緑岩

5.ゾイサイト

陽起石・曹長石岩

6. 蛇挍碧

7. 結昆片岩穎

（黒色片岩已緑色 片岩の互層より なる)

$x$

栄上磁鉄鍍偟地

$\times$

磁鉄鉱鷹地 
考えられるが，更に榆討を要する。

さきに緑色片岩と哹んだ岩吕は，外観淡緑色〜緑色片理の発達著しい岩 石で種々の岩相のものが舍まれるが, 主に陽起石，角閃石，緑筑石，緑泥 石，ゾイ少イト等の有色鉱物と其に多量の曹長石の変斑晶又は石英に富む 岩石で，特に蛇紋岩体の周辺部では曹長石の変斑晶を增すと交に陽起石， 藍閃石（又は直閃石）及び緑泥石をも増加する。時には黃鉄鉱を多量に生 ずるものもみられる。

黒色片岩は絹雲昌, 石墨, 石荚, 曹長石等を主成分鉱物とし, 簒々炭酸 塩鉱物，緑泥石，陽起石及び黃鉄鉱を生ずるものもある。

表題の磁䤮鉣は上述の蛇絞岩体に捅獲された，黒色片岩及び緑色片岩と の互層よりなる結晶片岩類と蛇紋岩との接蟲部に生じたもので, 結晶片岩 類は著しく曹長石の斑晶に富み，いずれも絹等母，陽起石，藍閃石及びゾ イサイト等を生じ，たぶ黒色片岩源と思われる部分では特に絹雲母:及び石 英に䈏む。

磁鉄鉱・緑泥石岩の分布は，この捕獲岩体の北辽部にそつて約 $50 \mathrm{~m}$ 程の

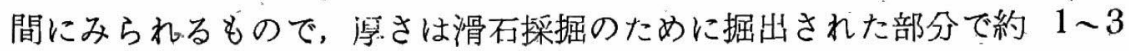
$\mathrm{m}$ 程である。

附近の地層の走向は $\mathrm{N} 10^{\circ} \sim 20^{\circ} \mathrm{W}$ ，東方へ約 $10^{\circ} \sim 5^{\circ}$ 内外の緩傾斜を示 し，磁鉄鉣・緑泥石岩にもこの方向の片理の発達がみられ，局部的にはあ たかも地層とは整合的に発達する。磁鉄鋕はこの岩の片理と平行に並ん で配外する場合が多く，時には相対する 2 つの 0 面が，特に発達した扁

第 2 図磁鉄鉱の変斑晶（結晶の粗な部分）

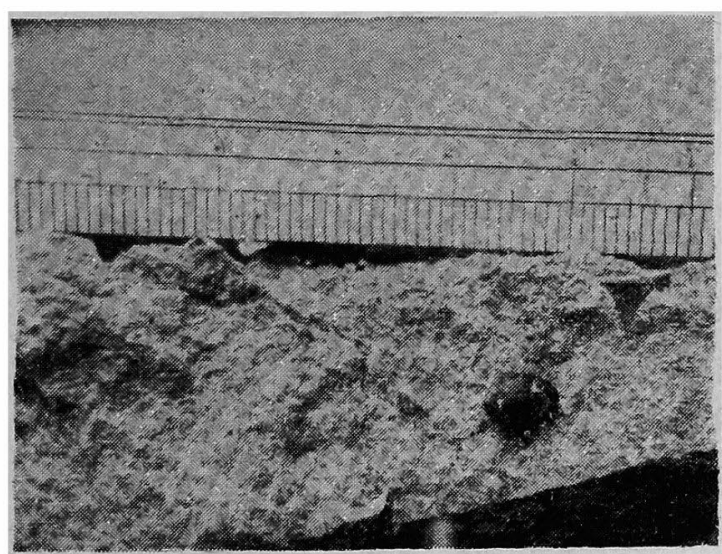

(スケールの数字は $\mathrm{cm}$ ) 
平状の結晶をみる事もある。緑泥石吡中でもその分标は一様でなく，誃量 に泌集して生じた個処では 1〜3mm 程で概して小さく，まぼらに生じた 部分では $1 \mathrm{~cm}$ にも達する大晶をみる事がある(第 2 図)。

なほ野拇半富では布巻北西方及び川原村朴場西方の，蛇紋岩と片岩上の 接触部にも栄上と全く同様な磁鉄鉣・緑泥石岩の発達を認める(第 1 図)。 かつて島津の鉱物標本として使用された磁鉄䤲を，西彼析郡大串村に発達 する，此等と全く同様な廒状の磁鉄鉣・緑泥石岩より得られたものであ る。

\section{碳 鐵 鑛 の 座 狀}

1. 磁鉄鉱緑泥石岩の産状

磁鉄鉝を含む緑泥石岩は第 3 図に示すが如く，曹長石・石英・緑泥石・ 陽起石・絹雲母片岩と蛇紋岩との揬触部に発達するもので，更に蛇紋岩と の間には滑石化蛇絞岩，又曹長石・石英・緑泥石・陽起石・絹雲母片岩と の間には緑泥石・曹長石・絹雲母・陽起石・透角閃石岩及び曹長石・緑泥 石・絹雲母岩の発澾をみる。この㴍な諸岩石の分布は筆者がさきに報告” した西彼杵半島に多数発達する滑石鉱林にみられる変質竹の分布と全く同 様な関係を示し，恐らく此処でも蛇紋岩と片岩との接触部にそつて上昇し 来つた溶液の作用に依つて磁鉄鉱・緑泥石岩を初め滑石化岩その他の諸変

第 3 図磁鉄鉣・緑泥石岩の産状（断面図）

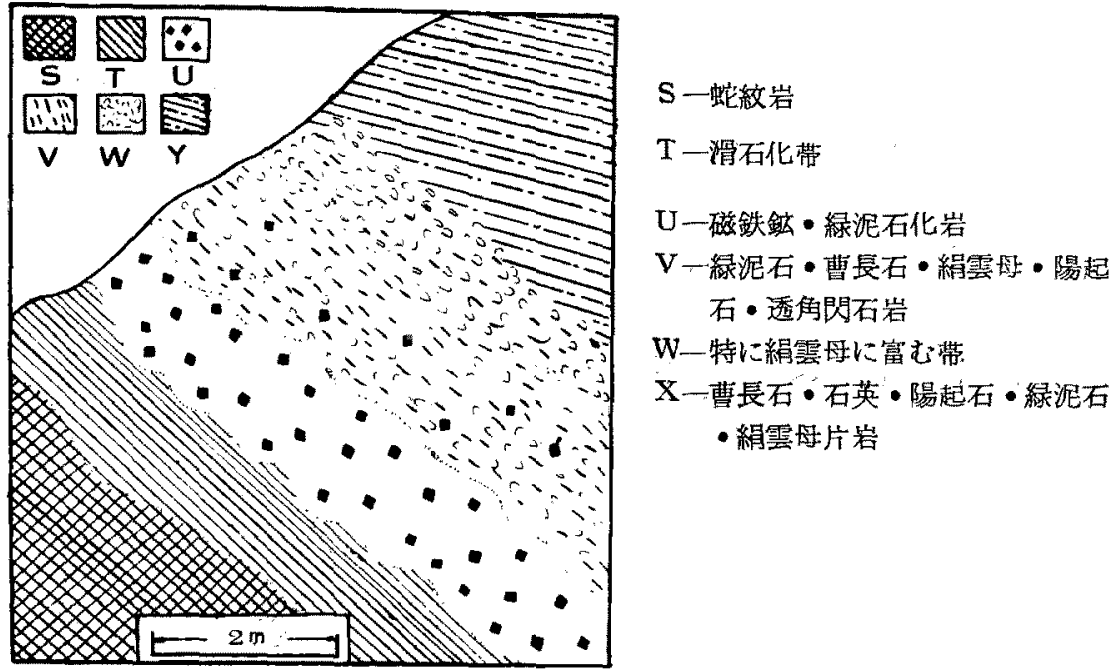

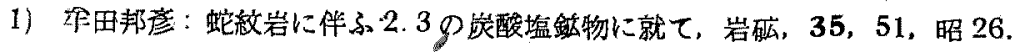


韻岩を生じた專が考えられる。

（1）蛇紋岩……緑黑色緻密塊状の岩石で，片岩に近ずくに従つて次述 の滑石化作用を蒙るため白咏を増す。頭徽鏡下でも磁鉄鋐・緑泥石岩に近 ずくに従つて，即ち岩体の縁辺部に近ずく程滑石の生成は著しくなる。此 等の滑石は明らかに蛇数石を交代して脈状攵は斑点状に生じ，この様な部 分では虬紋石中に包裹される壁埃状の微細な不透明鉱物がほとんぞみら れない事は注目に值する。灭この带の滑石は何等一定の方向性を示さず， 乱雑に生じている点が次述の滑石带に於ける滑石と異り，更にこの滑石中 には明らかな自形をなす炭酸湓鉣物を生ずる事がある。此様な若干の滑石 を生じた蛇紋岩の分析值は第 1 表（b) に示した。新鮮な蛇紋岩 (a)に 比べて, $\mathrm{SiO}_{2}$ の增加, $\mathrm{Fe}_{2} \mathrm{O}_{3}$ (Total $\mathrm{Fe}$ ), $\mathrm{MgO}, \mathrm{Al}_{2} \mathrm{O}_{3}$ 及ひ $\mathrm{H}_{2} \mathrm{O}$ の 減少が認められる。

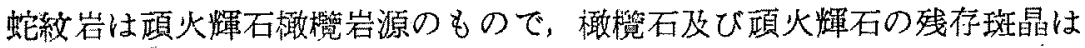
ほとんどみられず,多量の crysotile serpentineよりなる。

なほ蛇校岩中に於ける鉄鉱石には磁鉄鉱，チタン鉄鉱稀にフローム鉄鉝 を認め，蛇紋岩中の total $\mathrm{Fe}$ は約 $8 \% \mathrm{Fe}_{2} \mathrm{O}_{3}$ である。文鉄鉝石の大音 さは多くは $0.01 \mathrm{~mm}$ 程の赝埃状のものが多く，緑泥石岩中のものに比べ てはるかに小さいが，外形も後者程に完全な自形を示さず，半自形放至粒 状不定形をなして蛇紋石中に包赛され，後者とは可なりその産状を異にす る。

（口）滑石带……白色〜淡緑青色稍々片理の発達をみる吡石で，最も厚 い部分で約 $3 \mathrm{~m}$ 内外，多くは $50 \mathrm{~cm} \sim 1 \mathrm{~m}$ 程の厚さをなし，時には滑石 带をほとんど欠く部分もある。

滑石化の著しい部分は，顕徽鏡下でもほとんど䑲色〜淡緑色の滑石のみ よりなり，侱かに交代をま妨れた蛇紋石の外に微量の磁鉄鉣，チタン鉄 鉣，チタナイト及び炭酸堭鉱物之站に時に陽起石及び緑泥石を生ずるのみ で，蛇紋岩に比べて鉄鉣石の量は著しく乏しい。此等の滑石は光学性 $(+)$, 大さ約 $0.1 〜 0.3 \mathrm{~mm}$ 程の鱗片状集合体よりなるが，緑泥石带近くでは淡 緑色淞々粗糕な滑石を認むる事がある。

（八）緑泥石岩……緑黒色多少芹理を有する光沢ある岩石で，常に磁鉄 鉣の変斑晶を有するが，その量は一定しない。ほとんど緑泥石よりなる岩 死で，磁鉄鈗の外は時に黄鉃鉱の変斑晶を認むるも，他の带で屚々みられ るが如き曹長石の変玟晶は全くみられない。

粶泥石は長さ $0.05 〜 0.1 \mathrm{mim}$ 程の鱗片状をなし，この外テシナイト，ゾ イサイト時に少量の曹長石及び燐灰石を生ずる。文不透明鉣物には磁鉄鉱 
の外に少量の黃鉄鉱、黃銅鉱及び輝銅鉱を認むる。この带については更に 後述する。

（二）曹長石・緑泥石・陽起石・透角閃石岩营…この带は次の曹長石 ・陽起石・緑泥石・絹雲㖊岩带との間に約 1 2 $2 \mathrm{~m}$ 程の厚さで発達する。 この需の岩死に多量の針状結晶をなす透角閃石及び隄起石よりなりこの 外少量の緑泥石，絹雲厓及び曹長石を諗むる。此等の鉣物はいずれも母岩 の片理にそつて列び，時に磁鉄鉙の変斑晶を生ずる場合には，明らかに此 等の片理を切つている。

透角閃石は径 0.001 0.002mm 程の細い針状のものが多く，顕微鏡下

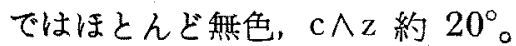

陽起石は淡黄〜淡青緑色を示す多色性を有し， $c \wedge z 2^{\circ} \sim 12^{\circ}$, 消光角の 小さなものは藍青色の多色性を示し，可なり整達質と思われるものもある。 此蓝は次の緑泥石・曹長石・陽起石・絹雲接岩に近ずくに従つて透角閃石 及び陽起石を減じ，且つ絧堅母を增す。又時に此带々接して曹長石の変斑 晶が著しく多い藍閃石・陽起石・緑泥石・曹長石・絹雲母岩をみる事もあ る。此場合綃雲団の増加は余り著しくなくこの稼な差違は絹雲母にとむ ものは黒色片岩源であり，曹長石に富むものは緑色片岩源のものと考えら れ，その源岩を異にするために起因するものと思われる。

（木）透角閃石・陽起石・石英・曹長石・絹筀母岩

前者を次述の黒色片岩との間に特に絹㹃母に富む岩石が発達する。厚さ は $1 \mathrm{~m}$ 以下で $20 \mathrm{~cm} \sim 50 \mathrm{~cm}$ 程の部分が多い。この带ではほとんど磁鉄 鉱の変斑晶はみられぬ。又透角閃石及じ陽起石の現出も著しく減ずる。

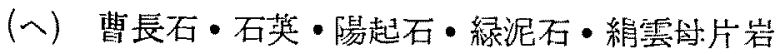

前者とは漸移的に移化し，前者に近い部分では特に片理の発達が著し い。外観常黒白色〜淡緑白色の片理に䈏む岩石で， $1 \mathrm{~mm} \sim 5 \mathrm{~mm}$ 程の曹長 石の変斑晶を生ずる。此曹長石と共に雯々 $0.1 \mathrm{~mm} \sim 1 \mathrm{~mm}$ 程の針状の陽 起石を認め，又此等の結晶を切つて黃鉄鋮の自形結晶を生ずる事がある。

石英は波動消光著しく，1 $\mathrm{mm}$ 以下の小さいモサイク状結晶集合体をな し，時に球状の包裹物を認むる。而して此等構成鉱物の間を充し，片理の 方们に立んだ羽王状の絹雲母が多数みられる。

然し前述の如人黒色片岩と緑色片岩上は互層をなすため，部分的に可成 り著しい共生鉣物の変化があり，緑色片岩源の部分では石英を欠き，曹長 石の変琣晶，陽起石及び緑沈石を增加する。なほ副成分銥物には鉄鉱石・ 瞵灰石・金紅石・クリノソイサイト・柘榴石等を認むる。

2. 共生鉱物 


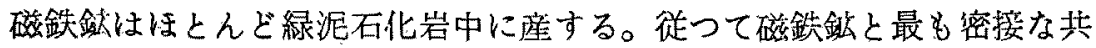
生銥物は線泥石である。この外磁鉄鉣の多い部分には必ずキタナイトがみ られる。又フリノソイサイト及じ曹長石をも伴うが，此等は前二者に比べ てはるかに少く，且つ余り密接な関係はみられ様である。

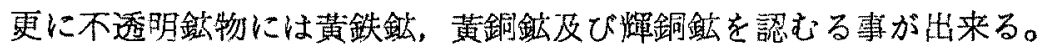

（1）緑沉石……肉眼的には淡緑色鱗片状集合体よりなり，蹎微鏡下で は，個マの解片の延長方向がほほ片理に平行なものが多い。文磁鉄鈆結晶 周辺部では㳟マ第 4 因にみるが如き pressure shadow を生じ，羽毛状の 緑泥石が磁鉄鉣片を中心にある方向性と市をつて生長して居り，第4図 では上下の方向にあたか子磁鉄鉉が移動して生じた架吵を緑泥石が㐎した 様な産状を示している。この様な羽毛状の綠泥石の成因は Mügge" や Pabst ${ }^{21}$ 等によつて説明が加えられているが，此場合も変頃作用の途上で

第 4 戍緑泥石による pressiure shadow.

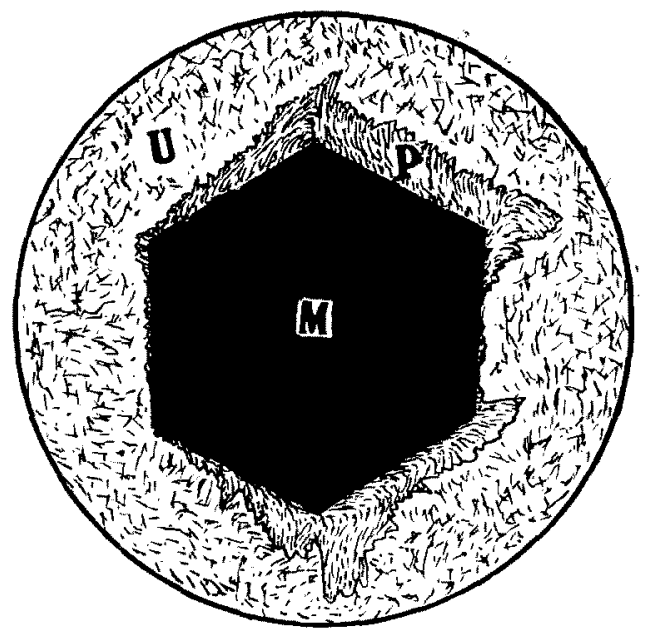

$\mathrm{P}$ 一悢泥石化による prssure shadow.

$\mathrm{M}$ 一磁鉄鉝 (約 $5 \mathrm{~mm}$ )

U一石基をなす緑泥石（不 規則な方向に結晶は発 達する)

絶えず外力が加わる様な状態のもとで，両鉱物が生舆した時，磁鉄鉙面上 に沈澱しつ、あつた緑泥石が；磁鉄鎕の移動に伴つて多少导張られ，又は 压縮されながら生長した〉め，かっる棈造を生じたものであろう。

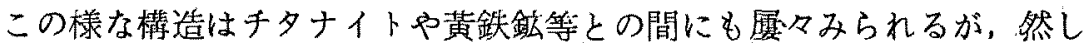

1) Mügge, $O$. : Uber die Entstehung faseriger Minerale und ihrer Aggregationsformen, Neu. Jah., Bei. 58A, 368-348.

2) Pabst, A. : "Pressure-shadows" and the measurement of the orientation of minerals in rocks. Am. Min., 16, 55, 1931 . 
一方では此等の鉱物中に常に緑泥石の包塞物を認め，又時には緑泥石の觶 片が明らかに磁鉄鉱の結晶によつて戓断される事があり，恐らく緑泥石の 晶出時期は可なり長く，磁鉄鉱の晶出より早く目つ痋い晆期迄続いたもの と思われる。

顕徽鏡下では $\mathrm{X}=\mathrm{Y}$ 淡緑，Z淡黃緑色の可なり著しい多色性をなし， $2 \mathrm{~V} \doteqdot 0$ 又は非常に小さい。光学性 $(+)$, 屈折率は $\alpha=1.592, \beta=\gamma=$

\subsection{5 の值を示す。}

第 3 表に示すが如き化学成分を有し，化学成分を一見すると鉄の多い clinochlore もしくは pennine に近い。然し

$$
\frac{\mathrm{FeO}}{\mathrm{FeO}+\mathrm{MgO}} \& \frac{\mathrm{Al}_{2} \mathrm{O}_{3}}{\mathrm{Al}_{2} \mathrm{O}_{3}+\mathrm{F}_{2} \mathrm{O}_{3}}
$$

との咸表"にプロツトすると Rip-Dia-Aph area に近いPen-Leo-Gro areaに位置する事が知られる。

\begin{tabular}{c|c} 
第 2 表 \\
\hline $\begin{array}{c}\mathrm{Al}_{2} \mathrm{O}_{3} \\
-\mathrm{Al}_{2} \mathrm{O}_{3}+\mathrm{Fe}_{2} \mathrm{O}_{3}\end{array} \times 100$ & $\frac{\mathrm{FeO}}{\mathrm{FeO}+\mathrm{MgO}}$ \\
\hline 90.6 & 12.53 \\
\hline
\end{tabular}

又分析值より化学式を計算すると約 $4 \mathrm{SiO}_{2} \cdot 2(\mathrm{Al} \cdot \mathrm{Fe} \cdot \cdots)_{2} \mathrm{O}_{3} \cdot 4(\mathrm{Fe} \cdot \cdot \mathrm{Mg})$ $\mathrm{O} \cdot 6 \mathrm{H}_{2} \mathrm{O}$ となり, pennine や clinochlore（純料なむの）よりも可なり 鉄に富み，むしろ鉄緑泥石と苦土緑泥石の中間に位置する種類に近い事が 知られる。

更にX 線粉末写真及び熱分析曲線を求めたが,”いずれもこれ迄に発表 された緑泻石群の鉱物のうち，鉄の稍々多い苦土悢泥石族の鉣物のデータ 一に近い。

熱分析曲線は籍 5 这の如く $556^{\circ} \sim 350^{\circ} \mathrm{C}$ で吸熱反伈( $\mathrm{Mg}-\mathrm{OH}$ group の分解)， $820^{\circ} \mathrm{C}$ 附近で強い吸熱 (Al-OH group の分解)， $800^{\circ} \sim 870^{\circ} \mathrm{C}$ 附近で热い発熱による (forsterite の生成?) ピークがそれぞれみられる。 この様な熱分析曲線は同図に列示した日立鉱山産及び諏訪鉱山附近の緑泥 片岩中2)のもの>曲線にほぼ一致する。なほ各ビークの温度には多少のう れはあるが，Ureka (Utah)の clinochlore の熱分析曲線に近似し，

1) 須藤俊男・関根良弘 新潟県蒛葡鉣山附近の所謂变朽安山岩中の緑泥石，岩鉱， $35,123,1951$.

2）須藤俊男・村岡 誠：粘土釷物の性質表， 1950 . 
第 5 园緑泥石の警分析曲瑔

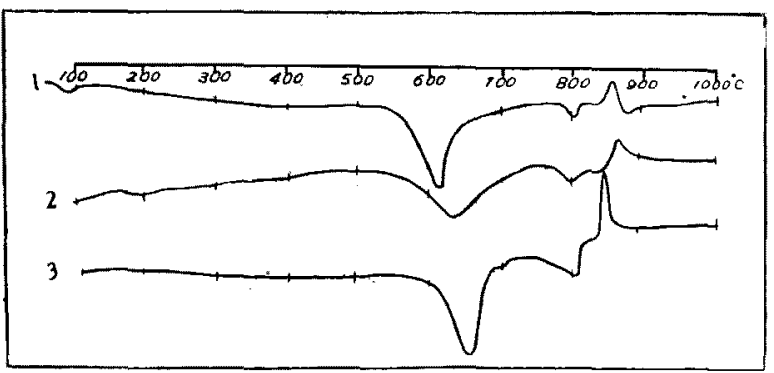

1. 蛟接栄上阵 緑泥石

2, 日立鉱山産"

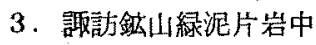
の緑洰石

prochlorite 及び Grim" 等が示した chlorite (pennine?) とは可なり異 つた碩问を示す。

$\mathrm{X}$ 線粉末学真を第 1 表 (a) 双び (b) に示す。用いた対隍極は鉄で， 電王。 $40 \mathrm{kV}$ ，電流 $5 \mathrm{~mA}$ で 4 時間行つた。各線はいずれ名明膫な細い線 で卢められる。

策 1 表 (a) X 線 粉末写真

\begin{tabular}{ll|ll|ll}
\hline d. & I. & d. & I. & d. & I. \\
\hline 1.13 & 3 & 2.03 & 5 & 3.99 & 2 \\
$1.22(5)$ & 4 & 2.28 & 2 & $4 \cdot 10$ & 1 \\
1.39 & 6 & 2.45 & 2 & 4.75 & 7 \\
1.42 & 2 & 2.57 & 2 & $5 ! 00$ & 4 \\
1.53 & 4 & $2.60(5)$ & 1 & 5.45 & 3 \\
1.57 & 5 & 2.87 & 7 & 7.15 & 7 \\
1.67 & 1 & 2.93 & 1 & 7.80 & 6 \\
1.82 & 2 & 3.38 & 10 & & \\
1.95 & 2 & 3.72 & 4 & & \\
\hline
\end{tabular}

第 1 表 (b) X 線 粉 末 写一真

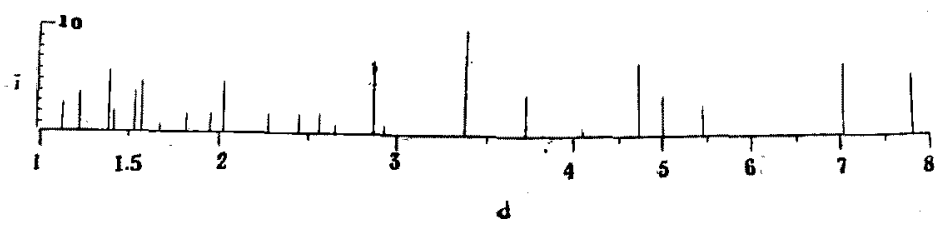

1) U. S. Geol. Sur. Ureka, Utah, 1945 ; Grim, R. E., Rowland, R. A.,: Am. Min., 27, 801 818, 1942. 
（口）黃鉄鉱……緑泥石中に芫全な自形絬晶としてみられる。磁鉄鉱の 多い部分にほ一般に少い。然し磁鉄鉱・緑泥石岩の下盤をなす岩石中には 霖々認められ，特に黃鉄鉱に富む部分では点々と結晶が竝んであたかも带 状又は脈状で発達する事がある。

磁鉄鉣と共生するものでは，磁鉄鍍を交代したり，又は切断したり，更 には磁鉄銅 = 緑泥石岩のある部分に特に多いという様な特別な共生関係は みられない。即ち磁鉄鉱の生成よりも早期又は晚期の生成物と思われる証 拠は何等みられぬ。却つて緑泥石の結晶による pressure shadow 構造も 磁鉄鉱と同様な関係でみられ，他の共生鉱物との関係よりしても，むしろ 磁鉄鉱とほほ同時期に晶出した事が考えられる。恐らく前者との相違点は 還元済特に $\mathrm{H}_{2} \mathrm{~S}$ の存在するか否かに依るものではなかろうか。

（八）黄銅鉣及び輝銅鉣…多くは磁鉄鉣・緑汇石岩の片理の方向に紨 く延びた不規則な小レンズ状（ウ $0.1 〜 0.5 \mathrm{~m}$ ，長さ $1 \mathrm{~m} \sim 1 \mathrm{~cm}$ 程のもの が多い)，時には片理を切つて発達するものもあり，更には磁鉄鎕結晶を 取眀んだり極めて稀には不明瞭に結晶を切つて発達するものもある。然し 一般には磁鉄鉣と密に共生する場合でも，明らかに磁鉄鉣を交代したり， 又は脆状で切断して黃銅鉱が発達する場合はほとんどなく，磁鉄鉱の結晶 面上にそつて単に黄銅鉱の沈澱が，これを取囲んでみられ好に過ぎぬ。 (7 図-(1)のb) 页この場合黄銅鉣は決して隣接する磁鉄鉱結晶中に包裹 される事なく，ほほ片理にそつて点々と不規則なレンズ状の小鉱塊が，可 なり連続して散在する。(この項続く）

第 7 図 (1-a)

片理にそつてほ心゙平行に立ぶ チタナイトと磁鉄銃との䦎係

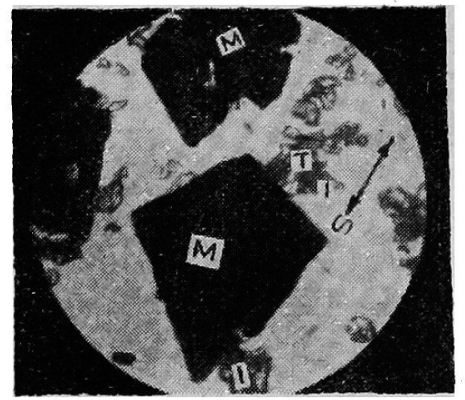

$\mathrm{M}$ 一磁鉄鉱 (結晶の大きさ約 $\mathbf{2} \mathrm{mm}$ ) T一チタナイト I一イルメナイト $\mathrm{S}$ 一矢印は母岩の片理の方向を示す $(1-b)$

磁鉄鉱の結晶のまわりに 生じた黄鉄鉣

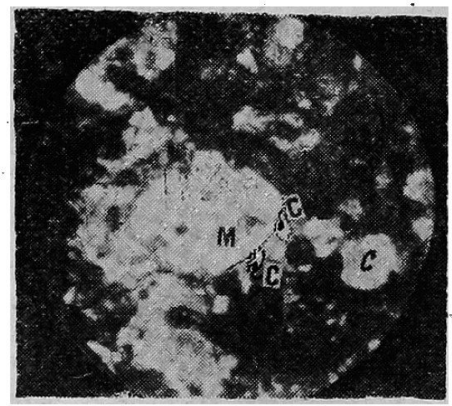

$\mathrm{M}$ 一磁鉄鉱 (結晶の大きさ約 $15 \mathrm{~mm}$ ) C一黄銅鉱 